\title{
'Mauritius' Lychee Fruit Development and Reduced Abscission after Treatment with the Auxin 2,4,5-TP
}

\author{
R.A. Stern \\ Kennedy-Leigh Center for Horticultural Research, The Hebrew University of Jerusalem, Faculty of \\ Agriculture, Rehovot 76100, Israel
}

J. Kigel

Department of AgriculturalBotany, The Hebrew University of Jerusalem, Faculty of Agriculture, Rehovot 76100, Israel

E. Tomer

The Institute of Horticulture, Agricultural Research Organization, The Volcani Center, Bet Dagon 50250, Israel

\author{
S. Gazit' \\ Kennedy-Leigh Center for Horticultural Research, The Hebrew University of Jerusalem, Faculty of \\ Agriculture, Rehovot 76100, Israel
}

Additional index words. fruit set, Litchi chinensis

\begin{abstract}
Fruit development and abscission in 'Mauritius' lychee (Litchi chinensis Sonn.) were studied over three consecutive seasons. Each season, two distinct abscission periods were observed. The first started at the end of full female bloom and continued for $\approx 4$ weeks. Of the initial number of female flowers, $85 \%$ to $90 \%$ abscised during this period. The second period began after a lag period of $\approx 1$ week and lasted $\approx 2$ weeks. About half of the remaining fruitlets abscised during this wave. AU of these fruitlets contained an embryo. The second wave coincided with a period of rapid embryo growth and endosperm loss. Tipimon (a commercial product containing the triethanolamine salt of the synthetic auxin 2,4,5-TP) consistently and significantly increased marketable fruit yield when applied between the two abscission periods. Chemical name used: 2,4,5 -trichlorophenoxy propionic acid (2,4,5 -TP).
\end{abstract}

Lychee produces many inflorescences with three flower types: male, female, and pseudohermaphrodite (Joubert, 1986; Stem et al., 1993b). Under normal conditions, each inflorescence bears $\approx 100$ to 250 female flowers. Only a small percentage of these develop into mature fruit after massive flower and fruitlet abscission. Most of the flowers and fruitlets abscise during the first month after pollination (Joubert, 1986; Mustard et al., 1953). It has been suggested that most of the abscised flowers and fruitlets are unfertilized due to failure of pollination or fertilization (Joubert, 1986; McConchie and Batten, 1989; Menzel, 1984). This abscission may be responsible for the generally low productivity of lychee trees (Galan-Sauco and Menini, 1989; Kadman and Slor, 1982; Shoan and Dhillon, 1981; Singh and Lal, 1980; Yuan and Huang, 1988).

Abscission of young fruit is a common phenomenon (Leopold and Kriedeman, 1975; Addicott, 1982). In several species, this abscission can be reduced or prevented by applying auxin (Leopold, 1958; Weaver, 1972). However, the specific relationship between auxin production in developing fruit and the massive fruitlet abscission in lychee has never been investigated (Menzel, 1984; Yuan and Huang, 1988; Galan-Sauco and Menini, 1989). Liu (1986) found that endogenous indoleacetic acid (IAA) content increases steeply during the first 3 weeks of fruit development in lychee, from 150 to $850 \mu \mathrm{g} \cdot \mathrm{g}^{-1}$ fresh weight, but decreases after the

Received for publication 1 Nov. 1993. Accepted for publication 23 May 1994, Contributionfromthe Faculty of Agriculture, P.O. Box 12, Rehovot 76100, Israel. We thank Hillary Voet for her valuable help in the statistical analysis. The cost of publishing this paper was defrayed in part by the payment of page charges. Under postalregulations,thispaperthereforemustbeherebymarkeda dvertisement solely to indicate this fact.

'To whom reprint requests should be addressed. onset of rapid embryo development, 4 to 5 weeks after full flower bloom (FFB), falling to $300 \mu \mathrm{g} \cdot \mathrm{g}^{-1}$ fresh weight.

Many studies have intended to prevent fruit abscission in lychee using synthetic auxins, mainly NAA ( $\alpha$ - naphthaleneacetic acid), 2,4-D (2,4-dichlorophenoxy acetic acid), 2,4,5-T (2,4,5trichlorophenoxyacetic acid) and 2,4,5-TP. In several of these studies, auxin reduced abscission (Khan et al., 1976; Prasad and Jauhari, 1963; Yuan and Huang, 1991), whereas in others it either had no effect (Hoda et al., 1973; Misra et al., 1973; Singh and Lal, 1980; Veera and Das, 1974; Verma et al., 1981) or increased abscission (Shoan and Dhillon, 1981). To date, using auxin commercially to reduce abscission and increase yield has not been reported in lychee (Galan-Sauco and Menini, 1989; Joubert, 1986; Menzel, 1984). In Israel, lychee fruitlet abscission was completely inhibited after spraying with Tipimon (a commercial product containing 2,4,5-TP) 1 to 3 weeks after FFB. However, most of the retained mature fruit were seedless, very small, and had no market value (Pivovaro, 1974). In another study, Tipimon failed to increase yield when applied to fruitlets 7 to 8 weeks after FFB (Shalem-Galon, 1980).

Lychee fruit and seed development has been described by Mustard (1960), Joubert (1967), Huang and Xu, (1983), and Chaitrakulsub et al. (1988), but the relationship between fruit and seed development stage and fruitlet abscission time was not determined, even in studies on applying synthetic auxins.

In this work, we first studied fruit development in 'Mauritius' lychee in relation to flower and fruitlet abscission. We identified the critical stage during fruitlet development at which applying synthetic auxins to the in florescence reduced abscission and enabled those with a developing seed to mature into normal, full-size fruit. Subsequently, we conducted a series of experiments in which 


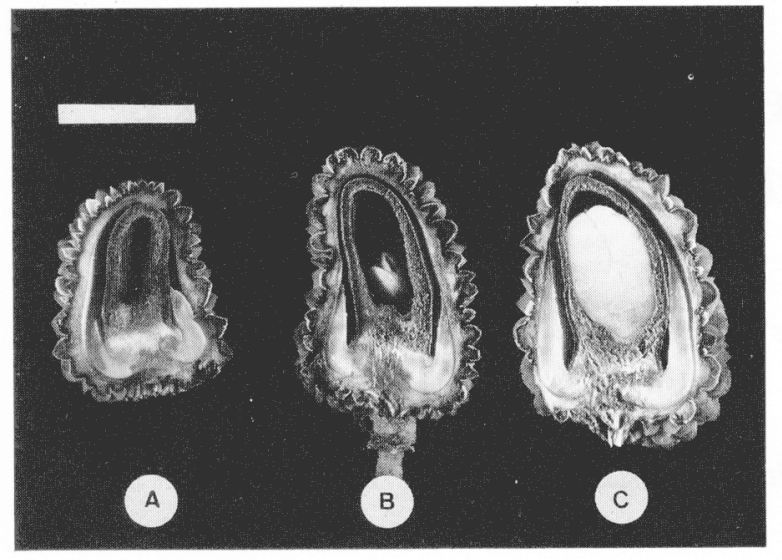

Fig. .1.L.'Mauritius'lychee fruitlets at three stages of development: (A) 4 week ( $\sim 1 \mathrm{~g})$. (B) 5 weeks old $(\approx 2 \mathrm{~g})$, and $($ C) 6 weeks old $(\approx 4 \mathrm{~g})$. Bar $=1 \mathrm{~cm}$.

we verified these resultsand established the parameters that would ensure an increase in marketable yield by spraying orchard trees with 2,4,5-TP.

\section{Materials and Methods}

Fruit development and abscission time was determined during 3 consecutive years $(1988,1989$, and 1990) by weekly observation of 12 inflorescences (two in each of six trees) on mature, 10- to 12year- old 'Mauritius' trees in lychee orchards in Ness-Ziona and Bet Dagan in the coastal plain of Israel. Fruit were sampled weekly (30/sample), weighed, then dissected. The pericarp, aril (the edible part), and seed were weighed separately.

Treating inflorescences with synthetic auxin. In 1988, lychee inflorescences on mature trees in Ness-Ziona were immersed for $10 \mathrm{sec}$ in 5-liter plastic buckets containing solutions of different synthetic auxins. Treatments were applied at three fruit development stages:

1) One week after FFB (May 1); inflorescences contained $\approx 160$ female flowers.

2) Five weeks after FFB (June 1), at the end of the first abscission period; inflorescences consisted of 10 to 17 (average 13) fruitlets $(\approx 2 \mathrm{~g}$ each), containing embryos that had reached the heart stage (Fig. 1B).

3) Seven weeks after FFB (14 June), at the end of the second abscission period; inflorescences consisted of 6 to 14 (average 10) fruitlets $(\approx 7 \mathrm{~g}$ each), containing nearly full-size embryos.

The following concentrations of synthetic auxins were used:

a) NAA (Sigma Chemical Co., St. Louis) at 20 ppm (Menzel, 1984; Pivovaro, 1974).

b) 2,4-D (Sigma) at 20 ppm (Menzel, 1984; Pivovaro, 1974).

c) $[(3,5,6$ trichloro-2-pyridinyl)oxy $]$ acetic acid (TR) (Tapazol, Rishon Lezion, Israel) liquid solution containing $48 \%$ triclopyr, 5,50, and 100 ppm a.i. (Tworkoski and Young, 1990).

d) Tipimon liquid solution containing $6.8 \% 2,4,5-\mathrm{TP}$, formulated as triethanolamine salt, 100, 400, and 600 ppm a.i. (Pivovaro, 1974).

The surfactant Triton X-100 was added to all solutions at $0.05 \%$. The control inflorescences were immersed in water containing the surfactant.

The experimental design consisted of ten randomized blocks

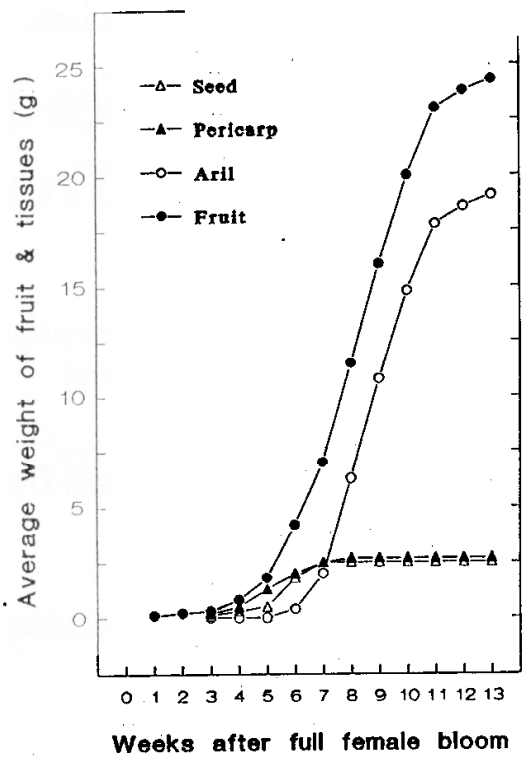

Fig. 2. Cumulative growth of 'Mauritius' lychee fruit, seed, pericarp, and aril in 1988. Each value is an average of 12 replicates.

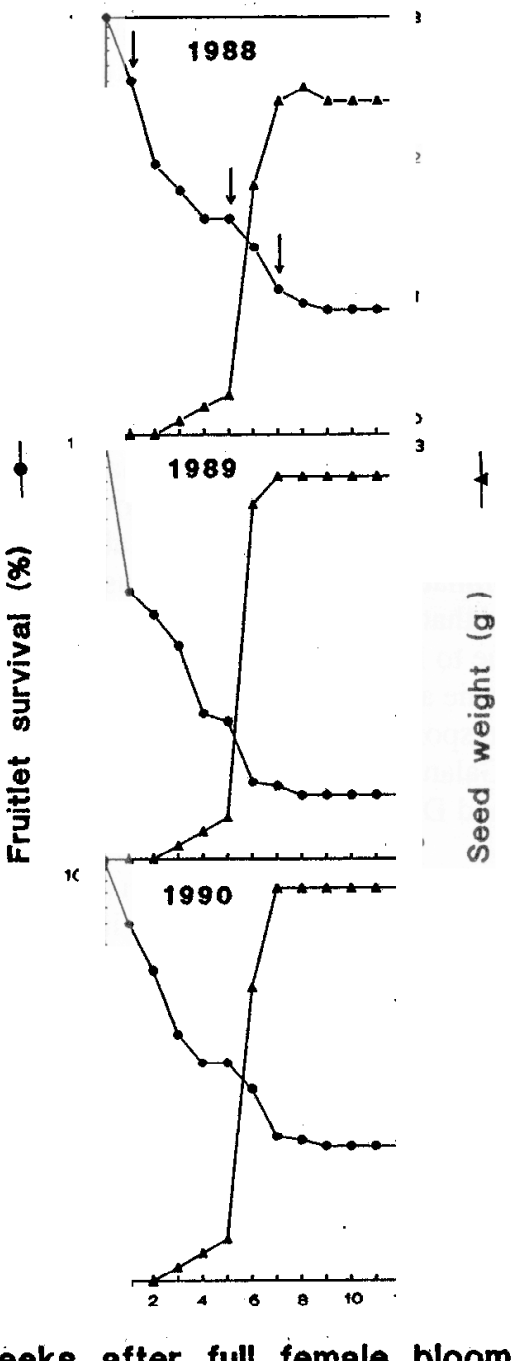

\section{Weeks after full female bloom}

Fig. 3. Patterns of 'Mauritius' lychee fruitlet abscission and seed growth. Initial number of female flowers per inflorescence was -160 . Each value is an average of 12 replicates obtained in 1988, 1989, and 1990. Arrows indicate synthetic auxin application times in 1988. 


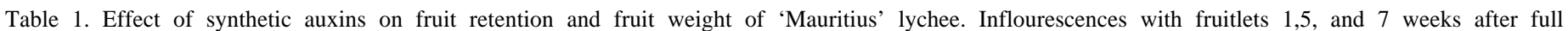
female bloom (FFB) were immersed for $10 \mathrm{sec}$ in the auxin solutions. Values were determined at harvest.

\begin{tabular}{|c|c|c|c|c|c|c|c|c|c|}
\hline \multirow[b]{3}{*}{ Substance $^{\mathrm{w}}$} & \multirow[b]{3}{*}{$\begin{array}{l}\text { Concn } \\
\text { (ppm) }\end{array}$} & \multicolumn{6}{|c|}{ Weeks after FFB } & \multirow[b]{3}{*}{$\begin{array}{c}\text { Fruit } \\
\text { wt } \\
(\mathrm{g})\end{array}$} & \multirow[b]{3}{*}{$\begin{array}{c}\text { Leaf } \\
\text { scorching }\end{array}$} \\
\hline & & \multicolumn{2}{|c|}{1} & \multicolumn{2}{|c|}{5} & \multicolumn{2}{|c|}{7} & & \\
\hline & & $\begin{array}{l}\text { No. of } \\
\text { fruitlets } \\
>10 \mathrm{~g}\end{array}$ & $\begin{array}{c}\text { Retained } \\
\text { fruitlets }^{x} \\
(\%)\end{array}$ & $\begin{array}{c}\text { Fruit } \\
\mathrm{wt} \\
(\mathrm{g})\end{array}$ & $\begin{array}{c}\text { Retained } \\
\text { fruitlets }^{y} \\
(\%)\end{array}$ & $\begin{array}{c}\text { Fruit } \\
\text { wt } \\
(\mathrm{g})\end{array}$ & $\begin{array}{l}\text { Retained } \\
\text { fruitlets } \\
(\%)\end{array}$ & & \\
\hline Control & & 7 & $4 c^{v}$ & $21.2 \mathrm{a}$ & $54 \mathrm{~cd}$ & $16.4 \overline{b c}$ & $87 a b$ & $18.9 \mathrm{ab}$ & $\overline{-}$ \\
\hline \multirow[t]{2}{*}{$2,4,5-\mathrm{TP}$} & 100 & 0 & $88 \mathrm{a}$ & $5.3 \mathrm{c}$ & $87 a$ & $16.7 \mathrm{bc}$ & 96 a & $18.8 \mathrm{ab}$ & - \\
\hline & 400 & 0 & $78 \mathrm{a}$ & $5.2 \mathrm{c}$ & $92 \mathrm{a}$ & $16.4 \mathrm{bc}$ & $97 a$ & $17.6 \mathrm{~b}$ & - \\
\hline . & 600 & 0 & $97 \mathrm{a}$ & $4.5 \mathrm{c}$ & $84 \mathrm{ab}$ & $10.7 \mathrm{~d}$ & $-\cdots$ & --- & + \\
\hline \multirow[t]{3}{*}{ 3,5,6-TR } & 5 & 6 & $4 c$ & $17.8 \mathrm{ab}$ & $50 \mathrm{~d}$ & $17.0 \mathrm{abc}$ & $96 a$ & $17.4 \mathrm{~b}$ & + \\
\hline & 50 & 4 & $4 c$ & $13.5 \mathrm{~b}$ & $67 \mathrm{~cd}$ & $16.4 b c$ & $88 \mathrm{bc}$ & $16.8 \mathrm{~b}$ & + \\
\hline & 100 & 7 & $9 \mathrm{~b}$ & $12.0 \mathrm{~b}$ & $71 \mathrm{bc}$ & $17.3 \mathrm{a}$ & $82 \mathrm{bc}$ & $17.0 \mathrm{~b}$ & + \\
\hline $2,4-\mathrm{D}$ & 20 & 4 & $3 c$ & $20.2 \mathrm{a}$ & $50 \mathrm{~d}$ & $18.4 \mathrm{~d}$ & $94 \mathrm{a}$ & $18.7 \mathrm{ab}$ & - \\
\hline NAA & 20 & 0 & $0 \mathrm{~d}$ & --- & $0 \mathrm{e}$ & -- & $68 \mathrm{c}$ & $18.8 \mathrm{ab}$ & - \\
\hline
\end{tabular}

'Initial number of 160 flowers per inflourescence.

${ }^{y}$ Thirteen fruitlets per inflorescence.

${ }^{x}$ Ten fruitlets per inflourescence.

"3,5,6-TR $=[(3,5,6$ - trichloro-2-pyridinyl) oxy $]$ acetic acid; 2-4-D = 2,4-dichlorophenoxy acetic acid; NAA $\ell$ - naphthaleneacetic acid

'Mean separation in columns by Duncan's multiple range test, $\boldsymbol{P}=0.05$.

(one tree per block, one inflorescence per treatment). Data were subjected to analyses of variance (ANOVA) and means were compared by Duncan's multiple range test. Percentage data was subjected to arcsin transformation before analysis to provide a normal distribution.

Spraying mature trees with Tipimon. The significant increase in marketable fruit retention after Tipimon treatment 5 weeks after FFB encouraged us to conduct a series of orchard experiments to determine the optimal parameters for a commercial procedure.

Six experiments were conducted on mature, 10-to-12-year-old trees in four orchards. Three of them (Kfar Hitim, Almagor, and Lavi) were commercial orchards located in the Lower Galilee region. One orchard was located at the Besor Experimental Station in western Negev. All orchards were regularly irrigated and fertilized during the dry season (April to November). In 1990 and 1992, autumnal water stress was used to promote flowering (Stern et al., 1993a). The vegetative condition of trees in the Lower Galilee orchards was excellent, whereas the Besor Experimental Station trees were weaker and somewhat chlorotic. Distances between trees in all four orchards were $6 \times 6 \mathrm{~m}(\approx 278$ trees/ha).

2,4,5-TP was applied at 50 to $200 \mathrm{ppm}$ a.i. The spraying equipment consisted of a) a motorized air-blower back sprayer (model DM9; Echo), which was used in Kfar Hitim (1989 and 1990), Besor (1991), and Lavi (1993); b) a regular back sprayer (Flood Jet TK 2.5; Solo), which was used in Besor (1990 and 1991 ); and c) a big commercial motorized gun sprayer (Holder), which was used at high pressure (20 atm) in Almagor ( 1990).

The experimental trees were harvested at the commercial harvest time. As a rule, fruit smaller than $15 \mathrm{~g}$ were not harvested or were discarded. Thus, yield data are only marketable fruit. One hundred fruit were sampled from each tree after harvest and weighed individually.

The experimental design was in randomized blocks. The number of blocks and the number of trees per block, respectively, were as follows: Kfar Hitim 1989, five and one; Kfar Hitim 1990, eighteen and one; Almagor 1990, four and five; Besor 1990, ten and one; Besor 1991, eight and one; Lavi 1993, five and one.

Data were analyzed for statistical significance using the general linear model (GLM) procedure. Duncan's multiple range test was used to compare treatments when ANOVA showed significant differences among means.

\section{Results}

Fruit growth and development. Similar growth patterns of the whole fruit and its tissues were observed in 1988, 1989, and 1990. Only data collected in 1988 are presented (Fig. 2). Cumulative growth patterns (pericarp, aril, and seed) were sigmoidal. Three distinct phases were distinguished.

1) The first phase ended 5 weeks after FFB. During this period, the main increment in fruit weight was due to pericarp growth. At the end of this phase the fruitlet weighed $\approx 2 \mathrm{~g}$ and the embryo had two developed cotyledons that could be seen with the naked eye when fruitlets were cut longitudinally (heart stage, Fig. 1B).

2) The second phase occurred 5 to 7 weeks after FFB. Seed growth was completed during this period, while the endosperm disappeared. At the end of this phase, the embryo filled the seed cavity with well-developed cotyledons, the seed coat had hardened, and the aril was just beginning rapid growth (Figs. 1C and 2). The fruitlet weighed $\approx 7 \mathrm{~g}$.

3) The third phase occurred 7 to 13 weeks after FFB. It was characterized by rapid aril growth $(\approx 3$ to $4 \mathrm{~g} /$ week from weeks 7 to 11 after FFB). The weight of the mature 'Mauritius' fruit ranged from 20 to $25 \mathrm{~g}$, of which the pericarp and seed each comprised $\approx 10 \%$ and the aril $\approx 80 \%$ of the total.

Abscission pattern. Similar patterns of female flower and fruitlet abscission were observed in 1988,1989, and 1990 (Fig. 3). Two distinct abscission periods were observed. The first one lasted for $\approx 4$ weeks. At the end of this period, $5 \%$ to $10 \%$ of the initial number of female flowers had survived and these developed into small fruitlets. One week later, a second abscission period began. Abscission rate was very high for 1 week in 1989 and for 2 weeks in 1988 and 1990, then decreased gradually and stopped almost entirely in the eighth to ninth week after FFB (Fig. 3). All fruitlets that abscised at this stage contained a well developed seed coat and an embryo (normal or defective) and weighed from 2 to $6 \mathrm{~g}$. During 


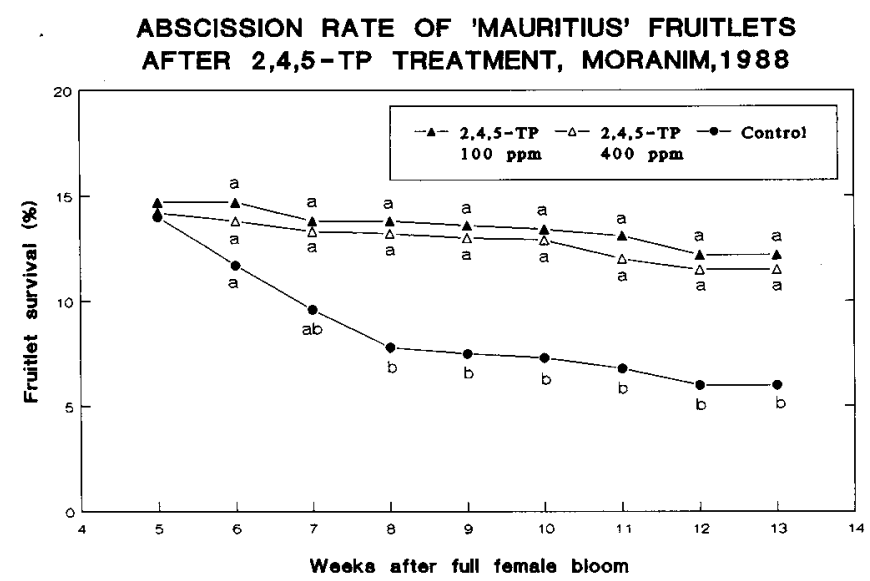

Fig. 4. Pattern of 'Mauritius' lychee fruitlet abscission in control inflourescences and after immersion in 2,4,5-TP at 100 or 400 ppm 5 weeks after full female bloom. Mean separation in each week by Duncan's multiple range test, $P=0.05$.

the second abscission period, about half of the remaining fruitlets abscised. Thus, only $3 \%$ to $59 \%$ of the initial number of female flowers developed into mature fruit.

Rapid embryo growth coincided with the second abscission period (Fig. 3). This relationship between seed growth and abscission was observed during each season. At the end of the second abscission period, a flush of vegetative sprouting occurred.

Effect of synthetic auxins on fruit abscission and fruit growth in inflorescences. 2,4-D, NAA, TR, or 2,4,5-TP was applied in 1988 at three fruit development stages (Fig. 3): a) 1 week after FFB, b) 5 weeks after FFB, before the second abscission period, and c) 7 weeks after FFB.

Only 2,4,5-TP consistently decreased fruitlet abscission significantly (Table 1). When applied 1 week after FFB, 2,4,5-TP treatments resulted in $78 \%$ to $97 \%$ retention of the female flowers compared to $4 \%$ in the control inflorescences. However, all fruit were small, seedless, and of no commercial value. 2,4,5-TP applied 5 weeks after FFB almost completely prevented further fruitlet abscission (Table 1, Fig. 4); fruitlet survival increased $\approx 70 \%$, from $54 \%$ to $84 \%$ to $92 \%$. Fruit weight was not affected by 100 or $400 \mathrm{ppm}$ (a.i.) 2,4,5-TP. Thus, these two treatments doubled the marketable fruit yield (Table 1, Fig. 4). When applied 7 weeks after FFB, 2, 4, 5-TP increased fruitlet survival to $\approx 96 \%$ to $97 \%$, but this increase was statistically insignificant due to high fruitlet retention in the control inflorescences $(87 \%)$. The highest 2,4,5-TP concentration $(600 \mathrm{ppm}$, a.i.) resulted in leaf scorching in the first and second experiments, and this treatment was therefore not applied in the third experiment.

None of the other three synthetic auxins reduced fruitlet abscission consistently (Table 1). In fact, $20 \mathrm{ppm}$ NAA increased fruitlet abscission significantly in all three experiments, whereas at the same concentration, 2,4-D-treated inflorescences did not differ significantly from the controls. The results obtained after applying TR were more complex: $100 \mathrm{ppm}$ TR decreased fruitlet abscission significantly (albeit much less than 2,4,5 -TP), when applied 1 week after FFB, but caused severe foliage scorching and inhibited vegetative sprouting.

Effect of 2,4,5-TP spray on whole trees. The effect of 2,4,5-TP on yield and marketable fruit weight in six experiments is presented in Table 2. In all experiments, one or more of the 2,4,5-TP treatments significantly increased marketable fruit yield. None of the treatments had a significant effect on marketable fruit weight. The factors studied in the experiments (concentration of 2,4,5-TP, volume per tree, and fruitlet weight at spraying) influenced the commercial effectiveness of the spraying.

Concentration and volume (Table 2). To avoid potential damage, we sprayed the trees in the first experiment (Kfar Hitim, 1989) with only 1 liter/tree; this small volume barely wet the foliage. The $200 \mathrm{ppm}$ a.i. treatment was much more effective than $100 \mathrm{ppm}$ a.i., whereas $50 \mathrm{ppm}$ a.i. gave results very similar to those of the controls. Despite the small volume, the highest concentration caused some leaf scorching. Volume was subsequently increased to 2 liters/tree for the motorized sprayer, 2.5 liters/tree for the big gun sprayer, and 5 liters/tree for the regular back sprayer. The amounts of 2 and 2.5 liters/tree did not wet the foliage to runoff, whereas 5 liters did. In 1990, 150 ppm a.i. increased marketable yield at Kfar Hitim and Almagor while causing only slight leaf scorching. In the same year, we used $200 \mathrm{ppm}$ a.i. at the Besor Experimental Station. This treatment was as effective as $100 \mathrm{ppm}$ a.i. in increasing yield but caused severe foliage scorching' and even branch dieback. Even $100 \mathrm{ppm}$ a.i. caused some foliage damage. In 1991 we compared the effect of the motorized sprayer and the regular sprayer using 50 and $100 \mathrm{ppm}$ a.i. No significant difference between sprayers and volumes was found. The smaller volume (2 liters/tree) caused a similar significant increase in marketable fruit with both sprayers. Some foliage and fruit scorching occurred, but there was no significant effect of sprayer type or volume. Using $50 \mathrm{ppm}$ a.i. was less effective than $100 \mathrm{ppm}$ a.i. In 1993 in Lavi, there was a significantly higher increase in marketable fruit using 50 compared to $100 \mathrm{ppm}$ a.i.

Fruitlet weight (Table 2). As a rule, we sprayed the trees when fruitlets weighed $\approx 2 \mathrm{~g}$ and the embryo could be seen when fruitlets were cut longitudinally (Fig. 1 B). In two experiments, we also sprayed $\approx 1$ week earlier, when fruitlet weight was $\approx 1 \mathrm{~g}$ and no embryo could be seen in the seed cavity (Fig 1A). In both cases, the earlier spraying was less effective in increasing marketable fruit yield. Spraying when fruitlet weight was only $1 \mathrm{~g}$ produced a lot of small unmarketable fruit. In 1990 we harvested all fruit in Kfar Hitim and found that the yield per tree of small fruit was $20.9 \mathrm{~kg}$ when sprayed at $1 \mathrm{~g}, 1.8 \mathrm{~kg}$ when sprayed at $2 \mathrm{~g}$, and $1.2 \mathrm{~kg}$ in the control trees. The difference between the first treatment and the last two treatments was significant. All fruit were also harvested in Besor's two experiments (spraying performed when fruitlet weight was $2 \mathrm{~g}$ ). In 1990, the yield of small fruit per tree was $1.3 \mathrm{~kg}$ in control trees and 3.9 to $5.0 \mathrm{~kg}$ in the treated trees. Small fruit yield in 1991 was $3.5 \mathrm{~kg}$ in control trees and $11.7 \mathrm{~kg}$ and $13.8 \mathrm{~kg}$ in the two treatments that increased yield significantly. All of the above differences were significant.

\section{Discussion}

The notable effectiveness of 2,4,5-TP in preventing fruitlet abscission in lychee has been known since 1974. However, its use did not increase marketable fruit yield (Pivovaro, 1974; ShalemGalon, 1980). Our consistent success in increasing marketable fruit yield in 'Mauritius' can be attributed to fruitlet developmental stage at the time of the 2,4,5-TP treatment. In all experiments, we obtained the best results when 2,4,5-TP was applied $\approx 5$ weeks after FFB, when fruitlet weight averaged $2 \mathrm{~g}$ and the embryo was emerging. When applied even 1 week earlier to 1 -g fruitlets (Figs. $1 \mathrm{~A}$ and 2, Table 2), there was either no increase in marketable fruit (Kfar Hitim, 1990) or only a partial increase (Lavi, 1993), compared to the significant increase after application to 2-g fruitlets. When 2,4,5-TP was applied to inflorescences 2 weeks later (7 weeks after FFB), the yield increase was insignificant. At 7 weeks it was too late to save most of the fruitlets abscised during the 
Table 2. Effect of 2,4,5-TP spraying mature 'Mauritius' lychee trees on marketable fruit on yield and weight.

\begin{tabular}{|c|c|c|c|c|c|c|}
\hline \multirow{3}{*}{$\begin{array}{l}\text { Fruitlet } \\
w t \\
\text { (g) } \\
\end{array}$} & \multicolumn{2}{|c|}{ Treatment data } & \multirow[b]{2}{*}{ Sprayer } & \multicolumn{2}{|c|}{ Marketable fruit yield } & \multirow{3}{*}{$\begin{array}{l}\text { Marketable } \\
\text { fruit wt } \\
\text { (g) }\end{array}$} \\
\hline & \multicolumn{2}{|c|}{$2,4,5 \mathrm{TP}$} & & \multirow[b]{2}{*}{$\mathrm{kg} /$ tree } & \multirow{2}{*}{$\begin{array}{l}\text { Increase } \\
(\%)\end{array}$} & \\
\hline & $\mathrm{ppm}$ & liters/tree & type $^{2}$ & & & \\
\hline \multicolumn{7}{|c|}{ Kfar Mitim, 1989} \\
\hline 2 & 0 & 1 & M & $11.4 b^{y}$ & --- & $25.1 \mathrm{a}$ \\
\hline 2 & 50 & 1 & M & $10.7 \mathrm{~b}$ & & $24.5 \mathrm{a}$ \\
\hline 2 & 100 & 1 & M & $17.2 \mathrm{ab}$ & --- & 23.9 a \\
\hline 2 & 200 & 1 & M & $27.8 \mathrm{a}$ & 144 & $24.7 \mathrm{a}$ \\
\hline \multicolumn{7}{|c|}{ Kfar Hitim, 1990} \\
\hline 1 & 0 & 2 & M & $33.3 \mathrm{~b}$ & $\cdots$ & $21.9 \mathrm{a}$ \\
\hline 1 & 150 & 2 & M & $36.5 \mathrm{~b}$ & 10 & $21.5 \mathrm{a}$ \\
\hline 2 & 150 & 2 & M & $57.1 \mathrm{a}$ & 71 & $21.8 \mathrm{a}$ \\
\hline \multicolumn{7}{|c|}{ Almagor, 1990} \\
\hline 2 & 0 & 2.5 & $\mathrm{C}$ & $14.2 \mathrm{~b}$ & --- & $19.0 \mathrm{a}$ \\
\hline 2 & 150 & 2.5 & $\mathrm{C}$ & $19.5 \mathrm{a}$ & 37 & $20.0 \mathrm{a}$ \\
\hline \multicolumn{7}{|c|}{ Besor, 1990} \\
\hline 2 & 0 & 5 & $\mathrm{R}$ & $33.5 \mathrm{~b}$ & --- & $23.8 \mathrm{a}$ \\
\hline 2 & 100 & 5 & $\mathrm{R}$ & $49.5 \mathrm{a}$ & 48 & $24.0 \mathrm{a}$ \\
\hline 2 & 200 & 5 & $\mathrm{R}$ & $48.5 \mathrm{a}$ & 45 & $23.7 \mathrm{a}$ \\
\hline \multicolumn{7}{|c|}{ Besor, 1991} \\
\hline 2 & 0 & 5 & $\mathrm{R}$ & $25.1 \mathrm{~b}$ & --- & $22.8 \mathrm{a}$ \\
\hline 2 & 100 & 2 & $\mathrm{R}$ & $53.1 \mathrm{a}$ & 112 & $22.5 \mathrm{a}$ \\
\hline 2 & 100 & 5 & $\mathrm{R}$ & $40.1 \mathrm{ab}$ & 60 & \\
\hline 2 & 50 & 2 & M & $43.4 \mathrm{ab}$ & 73 & $23.1 \mathrm{a}$ \\
\hline 2 & 100 & 2 & M & $51.4 \mathrm{a}$ & 105 & $23.3 \mathrm{a}$ \\
\hline \multicolumn{7}{|c|}{ Lavi, 1993} \\
\hline 1 & 0 & 2 & M & $31.4 \mathrm{C}$ & --- & $22.3 \mathrm{a}$ \\
\hline 1 & 100 & 2 & M & $44.6 \mathrm{bc}$ & 42 & $22.8 \mathrm{a}$ \\
\hline 2 & 50 & 2 & M & $69.6 \mathrm{a}$ & 122 & $22.1 \mathrm{a}$ \\
\hline 2 & 100 & 2 & M & $51.6 \mathrm{~b}$ & 64 & $22.4 \mathrm{a}$ \\
\hline
\end{tabular}

${ }^{2} \mathrm{M}=$ motorized; $\mathrm{C}=$ commercial; $\mathrm{R}=$ regular.

'Mean separation in columns by Duncan's multiple range test, $P=0.05$.

second abscission period, thus there was no substantial yield increase. To be fully effective, 2,4,5-TP had to be applied before the beginning of the second abscission period. Thus, application time is crucial. 2,4,5-TP should be applied during the 1 week lull between the first and second abscission periods. Pivovaro ( 1974) and Shalem-Galon (1980) failed to increase marketable fruit production because they did not apply $2,4,5-\mathrm{TP}$ at this critical time.

The second abscission period occurred during rapid embryo growth and subsided when the embryo reached full size. A pronounced decrease in IAA content has been found in lychee during this period (Liu, 1986). The substantial increase in fruit retention after applying an effective synthetic auxin (2,4,5-TP) during this period may be the result of increased auxin in the fruitlet, but we cannot be sure that this is the case. The fact that 2,4,5-TP effectively prevented abscission in lychee at all fruit development stages (Pivovaro, 1974) may point to another general effect such as the inhibition of the abscission process (Addicott, 1982).

$2,4,5$-TP spray at the 2 -g fruitlet weight prevented $\approx 80 \%$ of further fruit drop. However, good flowering, pollination, and fertilization, culminating in adequate initial fruit set, are prerequisites for a high final yield. In 1988 and 1990, fruit retention after the end of the first abscission period was $\approx 10 \%$, whereas in 1989 it was only $\approx 4 \%$. No 2,4,5-TP treatment could fully correct the low initial set in 1989 . Thus, though optimal 2,4,5-TP sprayings resulted in a significant increase in commercial yield, final yields fluctuated from 19.5 to 69.6 $\mathrm{kg} /$ tree $\left(5.5\right.$ to $\left.19.3 \mathrm{t} \cdot \mathrm{ha}^{-1}\right)$.
Based on six spraying experiments, we arrived at the following conclusions regarding optimal 2,4,5-TP treatment.

a) The right time for an effective treatment is when fruitlets weigh $\approx 2$ $\mathrm{g}$ and the embryo is emerging and can be seen with the naked eye. These parameters may be different in other cultivars.

b) A 2,4,5-TP concentration of $200 \mathrm{ppm}$ caused severe damage to foliage and branches in Besor (1990). We believe that the poor condition of the trees made them more susceptible. However, to be safe, $100 \mathrm{ppm}$ a.i. should not be exceeded. The success of 50 ppm a.i. in Lavi (1993) suggests further studies using sprays <100 ppm.

c) No pronounced differences were noted between 2 and 5 liters/tree. The minimal volume needed to wet the inflorescences seems to be sufficient. For the small Israeli trees, 2 liters/tree seems to be enough.

d) All three sprayers were effective.

That 2,4,5-TP decreases abscission of developing lychee fruit while NAA and 2,4-D do not agrees with prior reports from Israel (Pivovaro, 1974; Shalem-Galon, 1980) but contradicts reports from China and India (Prasad and Jauhari, 1963; Misra, 1973; Hoda, 1973; Veera and Das, 1974; Kahn, 1976; Singh and Lal, 1980; Singh and Phoght, 1984; Yuan and Huang, 1991). The differences in the effectiveness of these synthetic auxins in the various reports may be due to genetic differences between the lychee cultivars used, environmental conditions, or auxin appli- 
cation time. It is also possible that the commercial formulation used in Tipimon improved the effectiveness of 2,4,5-TP compared to the formulations used in other countries.

\section{Literature Cited}

Addicott, F.T. 1982. Abscission. Univ. of California Press, Berkeley.

Chaitrakulsub, T., P. Chaidate, and H. Gemma. 1988. Study of fruit development of Litchi chinensis Sonn. var. Hong-Huay. Jpn. J. Trop. Agr. 32:201-207.

Galan-Sauce, V. and V.G. Menini. 1989. Litchi cultivation. FAO, Rome. Hoda, M. N., N.B. Syamal, and V.S. Chhonkar. 1973. Effect of growth substances and zinc on litchi fruit drop. Indian J. Hort. 30:456-460.

Huang, H. and J. Xu. 1983. The development patterns of fruit tissues and their correlative relationships in Litchi chinensis Sonn. Scientia Hort. 19:335-342.

Joubert, A.J. 1967. Die bloei, Embriosak-, Embrio-en Verugontwikkeling von Litchi chinensis Sonn. cultivar HLH Mauritius. MS thesis. Univ. of Witwatersrand, Johannesburg, South Africa.

Joubert, A.J. 1986. Litchi, p. 233-246. In: S.P. Monselise (cd.). Handbook of fruit set and development. CRC Press, Boca Raton, Fla.

Kadman, A. and E. Slor. 1982. Litchi growing in Israel. Alon Ha-Notes $36: 673-688$

Khan, I., R.S. Misra, and R.P. Srivastava. 1976. Effect of plant growth regulators on the fruit drop, size and quality of litchi cultivar Rose Scented. Prog. Hort. 8:61-69.

Leopold, A.C. 1958. Auxin uses in the control of flowering and fruiting. Annu. Rev. Plant Physiol. 9:281-310.

Leopold, A.C. and P.E. Kriedman. 1975. Plant growth and development. 2nd ed. McGraw-Hill, New York.

Liu, J. 1986. Studies on the changes of endogenous indoleacetic acid and gibberellin during litchi fruit development. MS thesis. South China Agr. Univ., Guangzhou.

McConchie, C.A. and D.J. Batten. 1989. Floral biology and fruit set in lychee. Proc. 2nd Natl. Lychee Seminar, Cairns, Australia. p. 7 1-74.

Menzel, C.M. 1984. The pattern and control of reproductive development in lychee: A review. Scientia Hort. 22:333-341.

Misra, S.K., J.P. Nauriyal, and R.P. Awasthi. 1973. Effect of growth regulators on fruit drop in litchi. Punjab Hort. J. 13:122-126.

Mustard, M.J. 1960. Megagametophytes of the lychee (Litchi chinensis Sonn.). Proc. Amer. Soc. Hort. Sci. 75:292-303.

Mustard, M.J., S. Liu, and R.O. Nelson. 1953. Observations of floral biology and fruit setting in lychee varieties. Proc. Florida State Hort.
Soc. $66: 212-220$.

Pivovaro, S.Z. 1974. Studies on the floral biology and the influence of growth regulators on fruit set, size and drop of Litchi chinensis Sonn.. MS thesis. The Hebrew Univ. of Jerusalem.

Prasad, A. and O.S. Jauhari. 1963. Effect of 2,4,5 -trichlorophenoxyacetic acid and alpha naphthaleneacetic acid on "drop stop" and size of litchi fruits. Madras Agr. J. 50:28-29.

Shalem-Galon, M. 1980. Lychee: Fertilization, fruit set and storage. MS thesis. The Hebrew Univ. of Jerusalem.

Shoan, S. and B.S. Dhillon. 1981. Fruit drop pattern in litchi cultivars and its control by the use of auxins. Punjab Agr. India Prog. Hort. 13:91-93.

Singh, O.P. and K.P.S. Phoght. 1984. Effect of growth regulators on fruit drop, size and quality of litchi cv. Calcutia. Punjab Hort. J. 24:83-88.

Singh, U.S. and R.K. Lal. 1980. Influence of growth regulators on setting, retention and weight of fruits in two cultivars of litchi. Scientia Hort. 12:321-326.

Stem, R. A., I. Adato, M. Goren, D. Eisenstein, and S. Gazit. 1993a. Effect of autumnal water stress on litchi flowering and yield in Israel. Scientia Hort. 54:295-302.

Stem, R.A., S. Gazit, R. El-Batsri, and C. Degani. 1993b. Pollen parent effect on outcrossing rate, yield, and fruit characteristics of 'Floridian' and' Mauritius' lychee. J. Amer. Soc. Hort. Sci. 118:109-114

Tworkoski, T.J. and R.S. Young. 1990. Rate and time of triclopyr application to control Virginia creeper in a peach orchard. HortScience 25:443-445.

Veera, S. and R.C. Das. 1974. Effect of 2,4-D, NAA, GA and 2,4,5-T on initial set, retention and growth of fruits in litchi, var Muzaffarpur. Hort. Adv. 9:11-13.

Verma, S.K., B.P. Jain, and S.R. Dass. 1981. Preliminary studies on the evaluation of the effect of growth substances with minor elements in controlling fruit drop in litchi. Haryana J. Hort. Sci. 10:4-10.

Weaver, R.J. 1972. Plant growth substances in agriculture. Univ. of California Press, Davis.

Yuan, R. and H. Huang. 1988. Litchi fruit abscission: Its patterns, effect of shading and relation to endogenous abscisic acid. Scientia Hort. 36:281-292.

Yuan, R. and H. Huang 1991. Effect of NAA, NAA plus nucleotides on fruit set of lychee. Austral. Lychee Yearbook $1: 46-50$. 